\title{
Geodetic and Geotechnical Means of Sea Breakwaters' Monitoring System
}

\author{
Dainora Jankauskienè ${ }^{1,2}$, Marija Eidukevičiūtè ${ }^{1}$, Vitalijus Volkovas ${ }^{1},{ }^{1}$ Kaunas University of \\ Technology, ${ }^{2}$ Klaipeda State University of Applied Science
}

\begin{abstract}
The Baltic Sea breakwaters are important objects to ensure fluent operation of Klaipeda State Sea Port. To monitor their stability and reliability, the geodetic and geotechnical monitoring tecniques were developed and installed along the Southern and Nothern Breakwaters of Klaipèda. The monitoring system measures simulataneously points (prisms) set up on stones of the breakwater at specific locations and reinforced tetrapods, the tilting of towers which are located along the breakwaters, as well as observes the displacement in cracks of breakwater's concrete constructions and records the sea level. For these measurements the respective devices are used: electronic tacheometers, two-axial sensors, cracks-gauges and piezometers. The set of the recorded data samples was composed of 10,100 observations and was processed by special software "Settop auscultation". The monitoring shows the stability in breakwaters with no deformations or slumps unobserved. The created monitoring system used for the experiment approves the efficiency of application for continuous observations of the hydrotechnical structure.
\end{abstract}

Key words: monitoring system, measurements of breakwaters, geodetic instruments, sensors, data analysis.

\section{Introduction}

The breakwaters of seaports are of several types and their functions are very important for protection of the coast from negative effect of sea waves and storms. Mostly, main constructions of breakwaters are made of stones and even small damage of such construction can cause painful subsequences. Therefore, a regular control of breakwaters state is necessary to avoid the damage of any types of breakwaters.

The main task was to determine the value of motion frequency of construction elements. The reason of such movements (displacements) can be settlements of breakwaters' foundations, degradation of the breakwaters' constituent elements or storms. The biggest threat that can cause these negative factors is the destruction of objects. Recent modern monitoring systems that provide the possibility of geotechnical and geodetic monitoring now effectively allows preliminary assessment to track and predict the state of objects in real time.

The general purpose and structure of breakwater

Breakwaters are widely used all over the world, mainly to provide the shelter from wave action. This protection is primarily designed for vessels in port and for port facilities, but sometimes breakwaters are also used to protect valuable habitats that are threatened by the destructive forces of the sea or to protect beaches from erosion. Although the threat is usually caused by wave action, the protection against currents is also important. Additionally, breakwaters can prevent or reduce the siltation of navigation channels. In some cases, breakwaters also accommodate loading facilities for cargo or passengers. The general structure of the breakwater is provided in Fig. 1 with listed elements and their functions. 


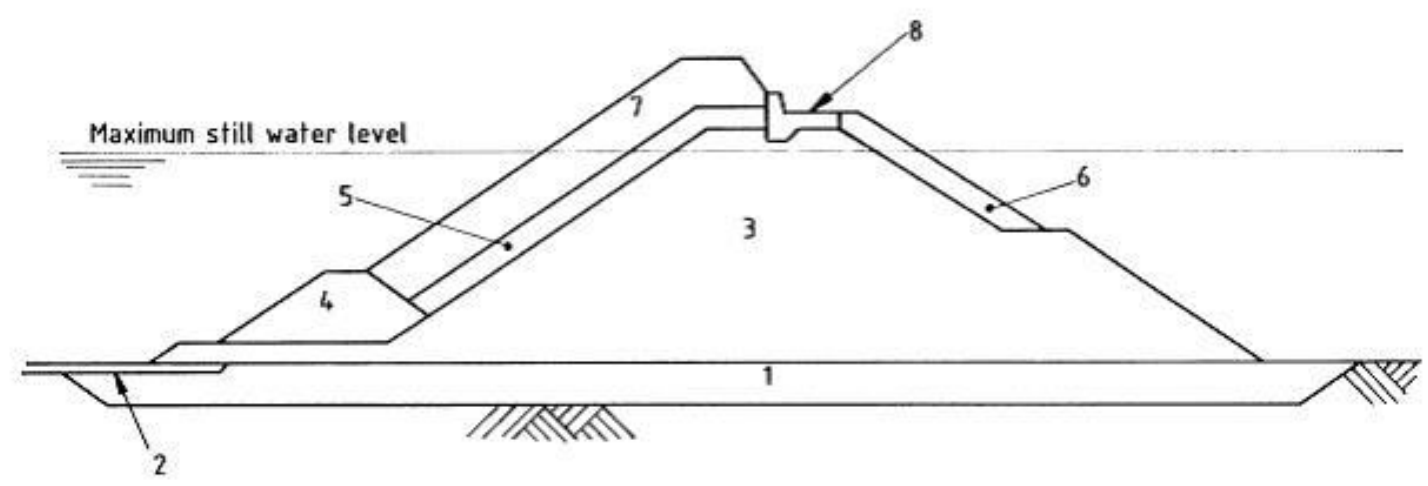

No. Element

Foundation improvement (if necessary)

Scour protection apron

Core

4 Toe mound

5 Underlayer

6 Rear face armour

7 Main armour

8 Concrete crest structure (with key or cut-off toe)

\section{Function}

Provides embankment stability

Prevents erosion

Provides bulk of structure and reduces wave transmission

Supports the main armour

Contains the core and provides foundation for armour

Protects core from overtopping waves. Provides wave protection inside harbour

Provides wave protection

Provides access and reduces overtopping (Key prevents sliding failure)

Fig. 1. Elements and their functions within typical breakwater (British Standard, 1991)

The object for experimental measurements is Northern and Southern Breakwaters of Klaipeda State Seaport (Fig. 2). General characteristics are the following: the structures are of inclined dams, reinforced by stones, concrete slabs and tetrapods;
Southern Breakwater has the length of 1,374 m, built in 1847-1861, 1900-1908; Northern Breakwater has the length of $733 \mathrm{~m}$, in 1834-1858; both were reconstructed in 2002 .
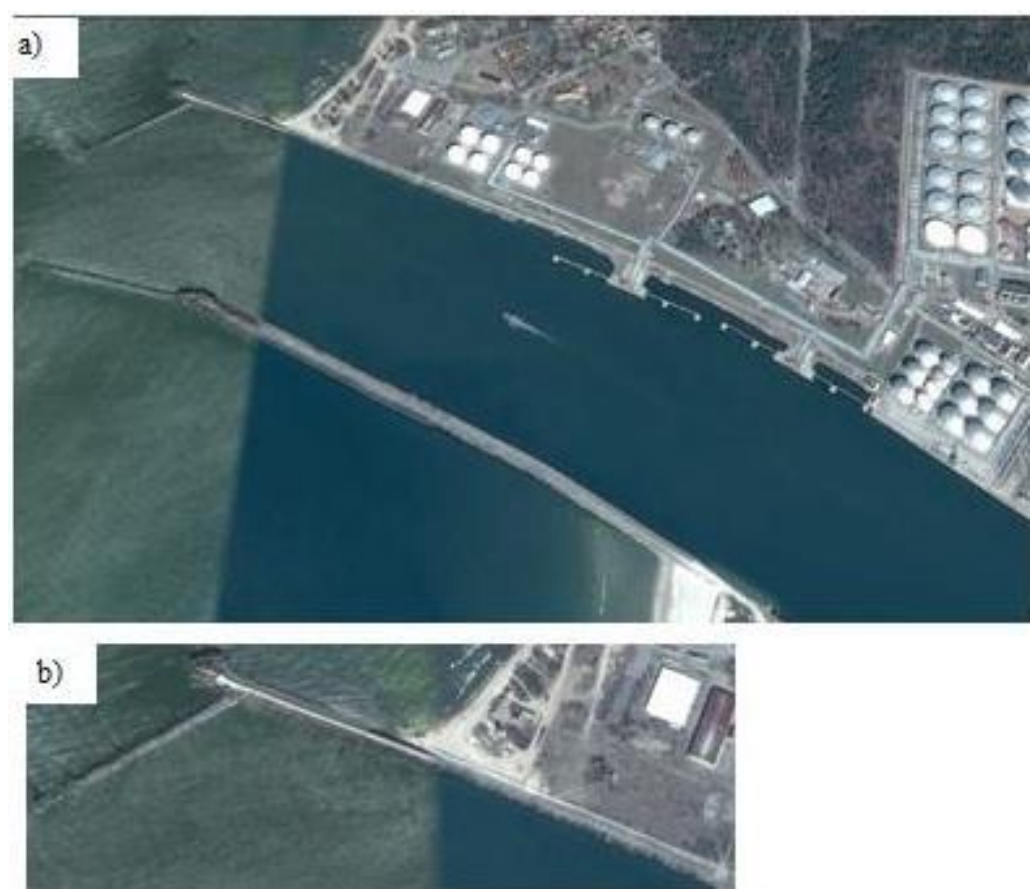

Fig. 2. Location of experimental objects - Northern and Southern Breakwater of Klaipeda State Seaport: a) general view b) Northern zoomed (from Google Earth application) 


\section{Monitoring methodology and means}

To monitor the parameters and a condition of Klaipeda breakwaters, the system includes the instruments used both for geodetic and geotechnical monitoring of the environment. The geotechnical monitoring uses the means and instruments attributed to geotechnical engineering. According to the definition from (Bucksch H., Dictionary..1997), it is the part of civil engineering involving the interrelationship between the geological environment and the works of man. It has a wide application and various parameters of the building have to be surveyed: the changes in the structures' position (in horizontal/vertical direction), atmospheric condition to evaluate their influence on the structure's characteristics and so on.

In comparison with other monitoring techniques, such as high-definition surveying and remote sensing and geotechnical instrumentation techniques, the geodetic deformation monitoring techniques are based on the ground surface network of points interconnected by angle and/or distance measurements; they measure only the ground surface deformations.

For breakwaters' monitoring in Klaipeda sea port, the function of geodetic monitoring is performed by a tacheometer, an electronic geodetic instrument of the high accuracy. The tacheometer is fixed on the support and mounted inside a special cabin (box) with openings for prevention of the environment actions. The cabin protects the instrument from the snow, rain and vandalism. The electronic tacheometer performs measurements automatically according to an indicated cycle. The night time is recommended for measurements to avoid refraction influence when working in daytime. Before each cycle of measurements, targeting of tacheometer to reference points is done automatically, that is necessary for recalculating coordinates of stations. The accumulator collects data of measurements and transmits to the main server. Points for monitoring are arranged in a spatial mode by prisms. The special program is used for processing of measurements' results.
Geotechnical monitoring includes the usage of such instruments or sensors: tilt sensors, cracksgauges and piezometer. All these sensors are connected to one network.

Tilt meters are fastened to the tower construction at different height for determination of towers' tilts and directions. Tilts in two perpendicular directions $(a, b)$ (Fig. 3) are calculated according to the formula:

$$
\begin{aligned}
& z=\frac{l}{\sqrt{\tan ^{2} \varphi+\tan ^{2} \omega+1}} \\
& b=z \cdot \tan \phi \\
& a=z \cdot \tan \omega
\end{aligned}
$$

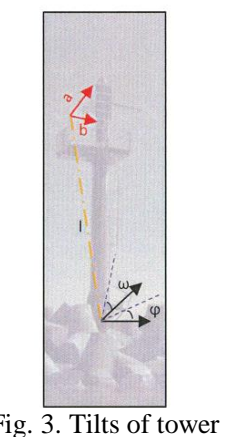

The cracks-gauges are located in these places where cracks are the biggest (about $10 \mathrm{~mm}$ ), when inspecting the breakwaters' construction. The piezometer is arranged besides the tower for observation of the sea level. The instrument is placed in the iron pipe (length $-3 \mathrm{~m}$, width $-15 \mathrm{~cm}$ ) and sunk into the sea water. The piezometer continually measures the pressure of water. The pipe should be arranged not vertically, but inclined and attached to the stones and bottom.

The software "Settop auscultation" is used for data processing, visualization and report preparation from all sensors. The presentation of measurements' results in graphics (diagrams) and numerical forms are possible (Fig. 5). A warning system is active and information is transmitted immediately, if damages of objects exceed indicated standards. All results of measurements are presented online in real time. 


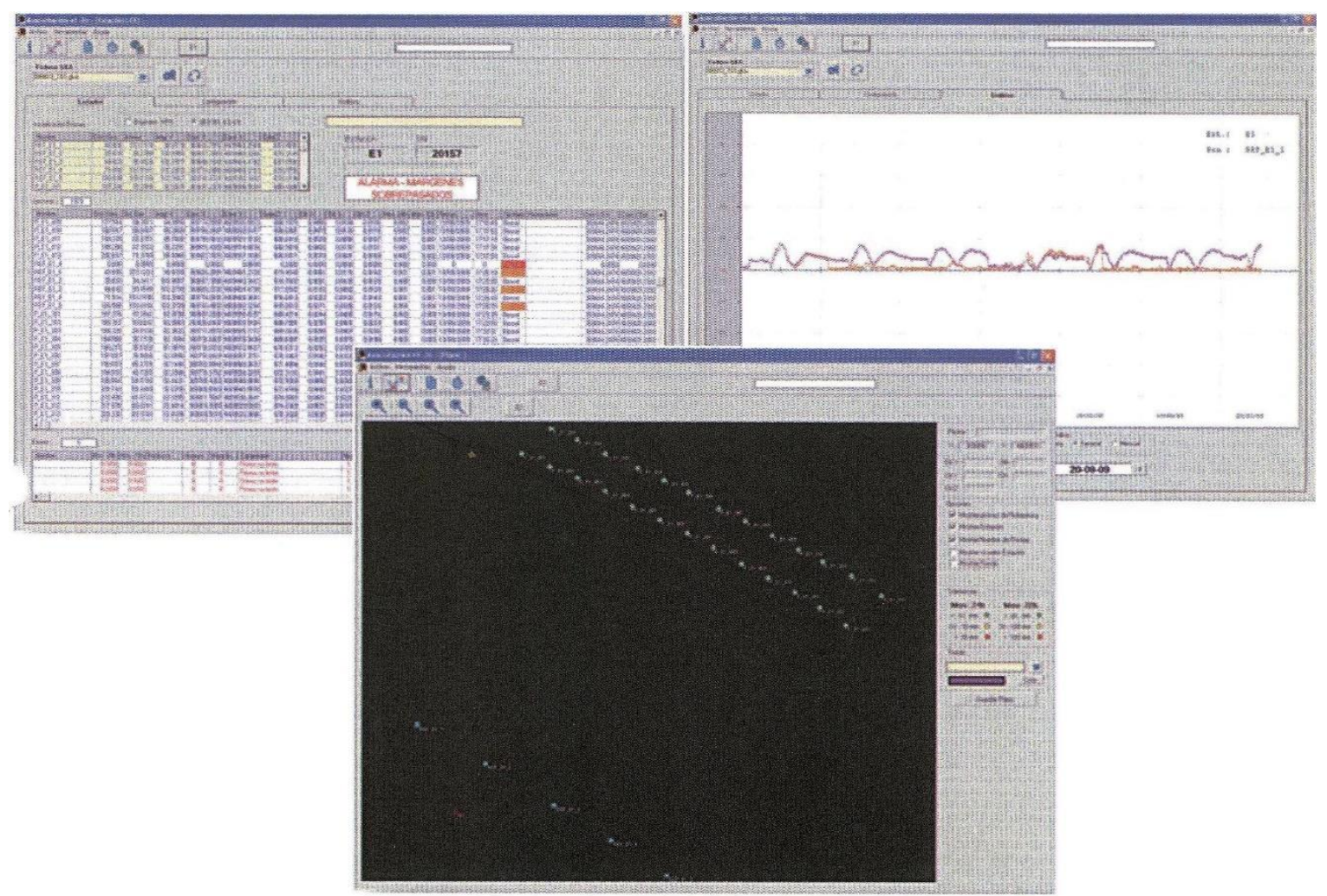

Fig. 4. Fragment of reporting data from "Settop auscultation" software

Description of elements for fixing structural changes and used measuring instruments are presented in Table 1 . The shortest distance from the tacheometer to measuring prisms is $70 \mathrm{~m}$ and the longest $-650 \mathrm{~m}$. Instruments are calibrated before measurements.

Description of monitoring elements and used technical means

\begin{tabular}{|c|c|c|c|c|}
\hline No. & $\begin{array}{c}\text { Measuring } \\
\text { instruments* }\end{array}$ & $\begin{array}{l}\text { Measured } \\
\text { elements }\end{array}$ & $\begin{array}{l}\text { Required } \\
\text { accuracy }\end{array}$ & Description \\
\hline 1 & $\begin{array}{l}\text { Electronic tacheometers } \\
\text { "Trimble S8", data } \\
\text { accumulator "Settop } \\
\text { M1", internet } \\
\text { connection 3G }\end{array}$ & $\begin{array}{l}\text { Points, } \\
\text { arranged on } \\
\text { stones and } \\
\text { reinforced } \\
\text { tetrapods }\end{array}$ & $\begin{array}{l}1.1 \mathrm{~mm} \\
\mathrm{~m}\left(0.5^{\prime \prime}\right)\end{array}$ & $\begin{array}{l}\text { Points fixed by prisms are distributed along } \\
\text { breakwaters on the side of Curonian Spit: at } \\
\text { Northern older part }-9 \text { points with intervals of } \\
50 \mathrm{~m} \text {, at newest }-8 \text { points with } 18-28 \mathrm{~m} \text {; at } \\
\text { Southern }-34 \text { points. Two tacheometers used } \\
\text { for measurements were set up on the seaport } \\
\text { territory, as well } 5 \text { reference points and } 2 \text { points } \\
\text { of geodetic network (see Figures } 5,7 \text { ). }\end{array}$ \\
\hline 2 & $\begin{array}{l}\text { Two-axial sensors } \\
\text { (gauge), "Geosense } \\
\text { MEMS Tilt Meter", } \\
\text { data accumulator } \\
\text { "Geosense Wi- SOS400 } \\
\text { Biaxial" }\end{array}$ & $\begin{array}{l}\text { Tilts of } \\
\text { towers }\end{array}$ & $\begin{array}{l} \pm 0.005 \\
\operatorname{mrad}\end{array}$ & $\begin{array}{l}\text { Determination of } 4 \text { towers' tilts at two } \\
\text { perpendicular directions (A and B) and } \\
\text { directions: } 2-\text { on Southern (sensors at } 10 \mathrm{~m} \\
\text { heights) and } 2-\text { on Northern breakwaters (Figs } \\
6,7) \text {. }\end{array}$ \\
\hline 3 & $\begin{array}{l}\text { The cracks-gauge } \\
\text { "Geosense } \\
\text { VWCM4000", } \\
\text { accumulator "Wi- } \\
\text { SOS400 VWNode" }\end{array}$ & $\begin{array}{l}\text { Cracks of } \\
\text { breakwaters' } \\
\text { concrete } \\
\text { constructions }\end{array}$ & $\begin{array}{l} \pm 0.1 \% \text { of } \\
\text { measured } \\
\text { value }\end{array}$ & $\begin{array}{l}\text { Observation of } 6 \text { locations on Southern } \\
\text { breakwater and } 4-\text { on Northern. }\end{array}$ \\
\hline 4 & $\begin{array}{l}\text { The piezometer } \\
\text { "Geosense VWP3300", } \\
\text { accumulator "Wi- } \\
\text { SOS400 Node" }\end{array}$ & $\begin{array}{l}\text { Sea level } \\
\text { changes }\end{array}$ & $\begin{array}{l}1 \mathrm{~cm} / \\
0.1^{0} \mathrm{C}\end{array}$ & Beside Southern breakwater's tower. \\
\hline
\end{tabular}




\section{Monitoring results}

The data from the measurement points were recorded once per 24 hours; at night time - on 0.00 hr. 3D positions' determination and detection of changes (displacements) are results of observations. The piezometer was recording the data at $6.00 \mathrm{hrs}$.

The analysis of breakwaters' monitoring (results from 15 measurements' cycles) was carried out using reported data set:
- daily displacements (in $\mathrm{x}, \mathrm{y}$ and $\mathrm{z}$ directions) of each point (prisms),

- towers tilts at two perpendicular directions,

- changes of cracks,

- sea level differentiations.

Figures 6-9 present the reported data examples from Southern breakwater measurements during a month's period (2015, 16.08-15.09) showing an example of the reported data.

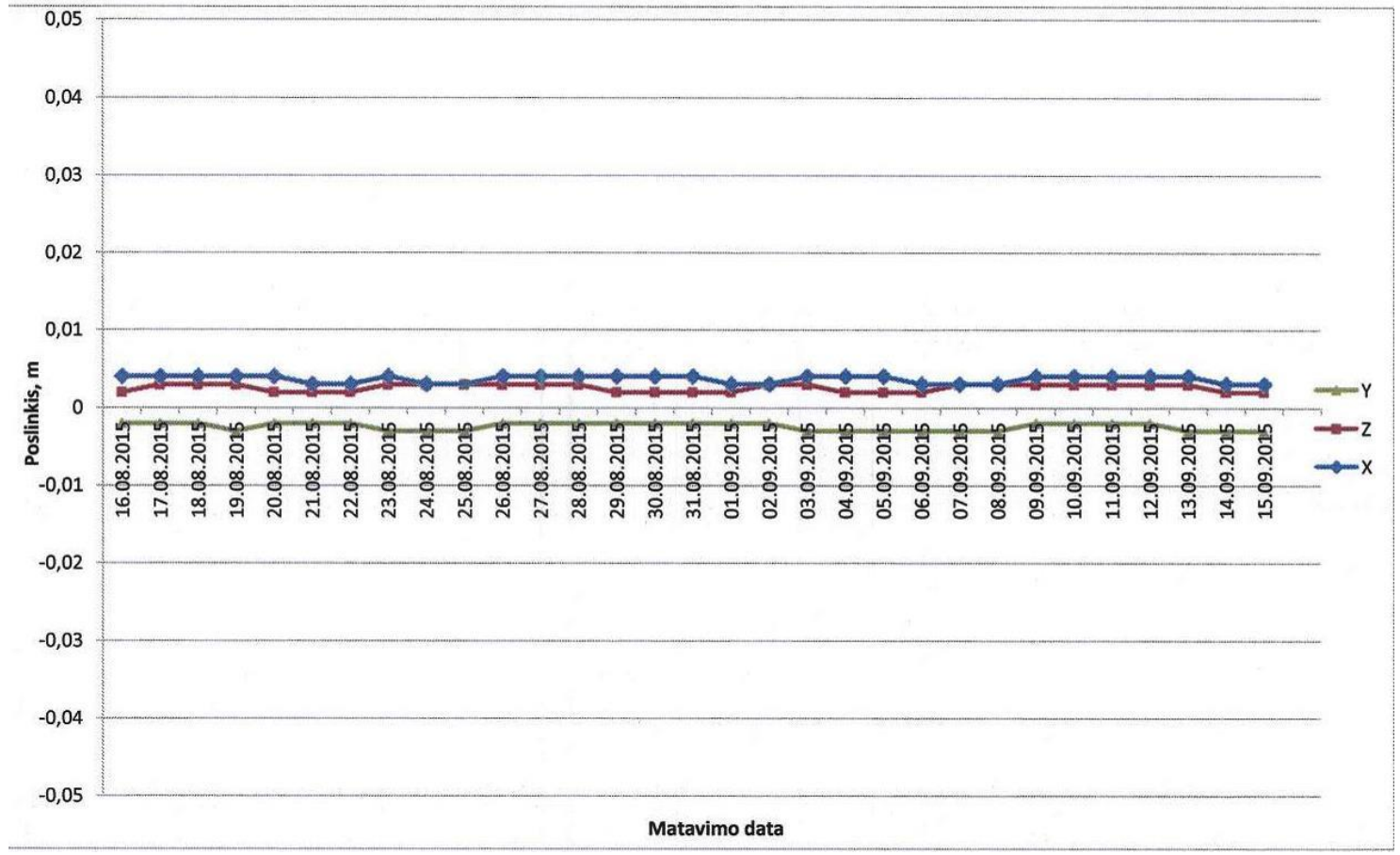

Fig. 5. Diagram of displacements defined from measurement of Southern Breakwater point (prism No.23) during the month: the maximal displacement is in $\mathrm{x}$ direction $-4 \mathrm{~mm}$

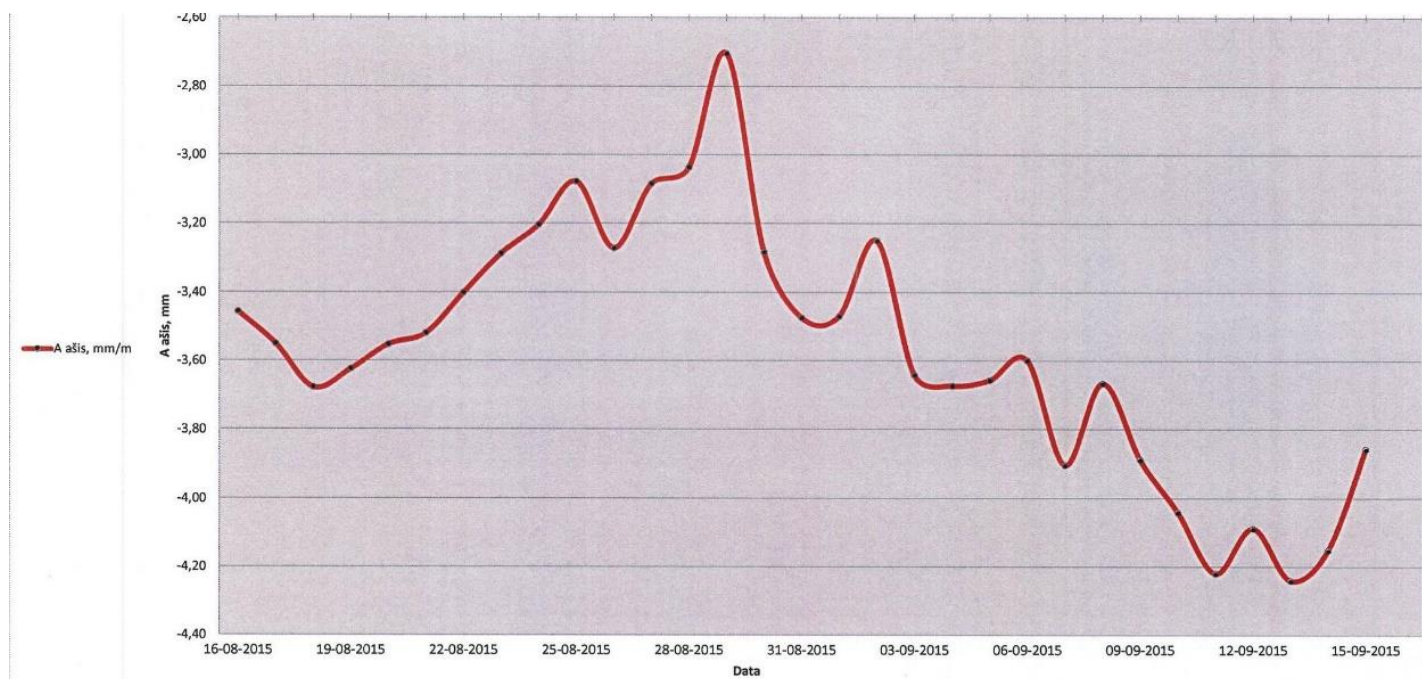

Fig. 6. Diagram of tower tilts at Southern Breakwater's newest part (A axis, sensor No.676): the maximal tilt $-4.25 \mathrm{~mm}$ 


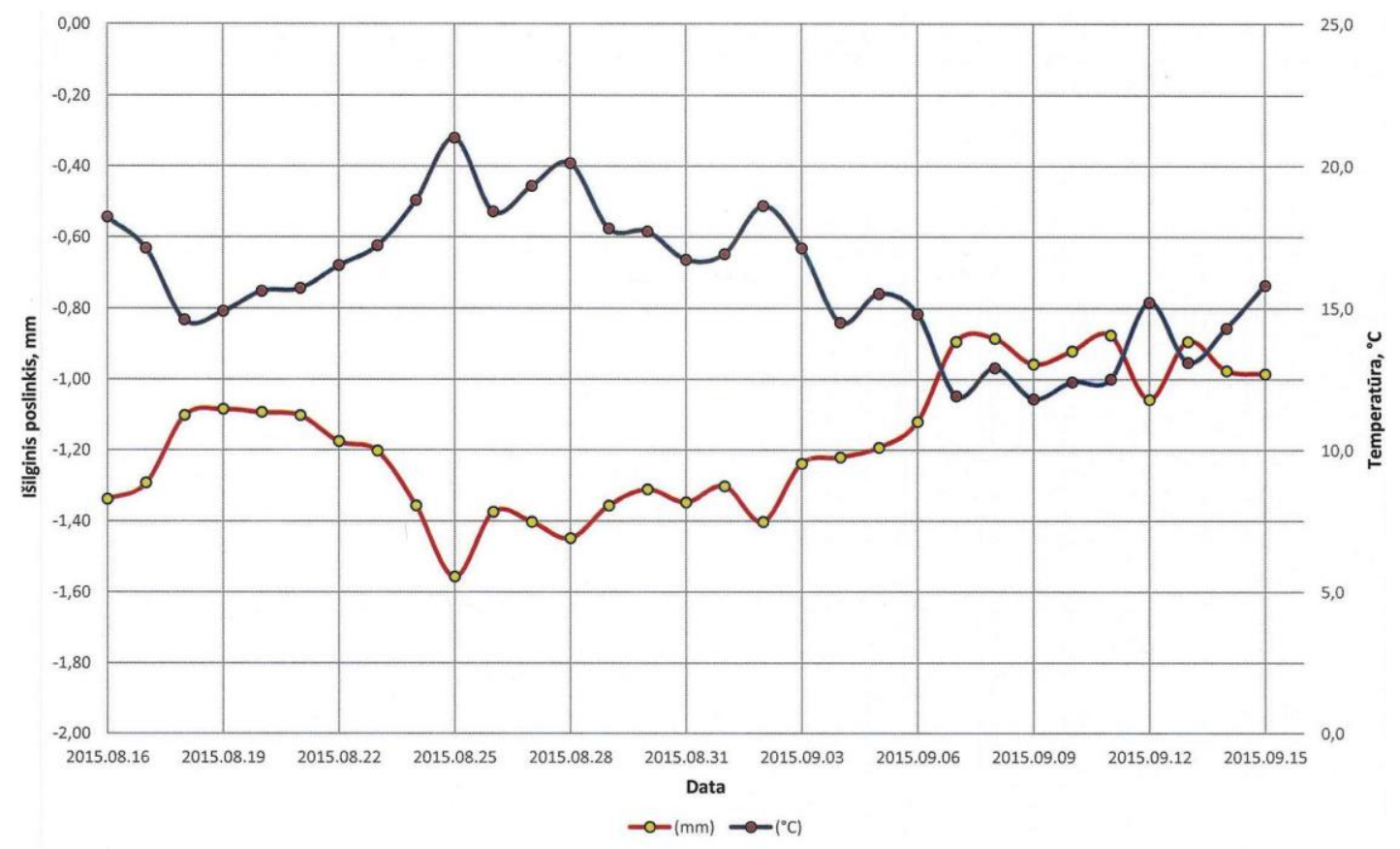

Fig. 7. Diagram of a crack values (Southern Breakwater, 493 m, crack-gauge No 629) and temperature changes

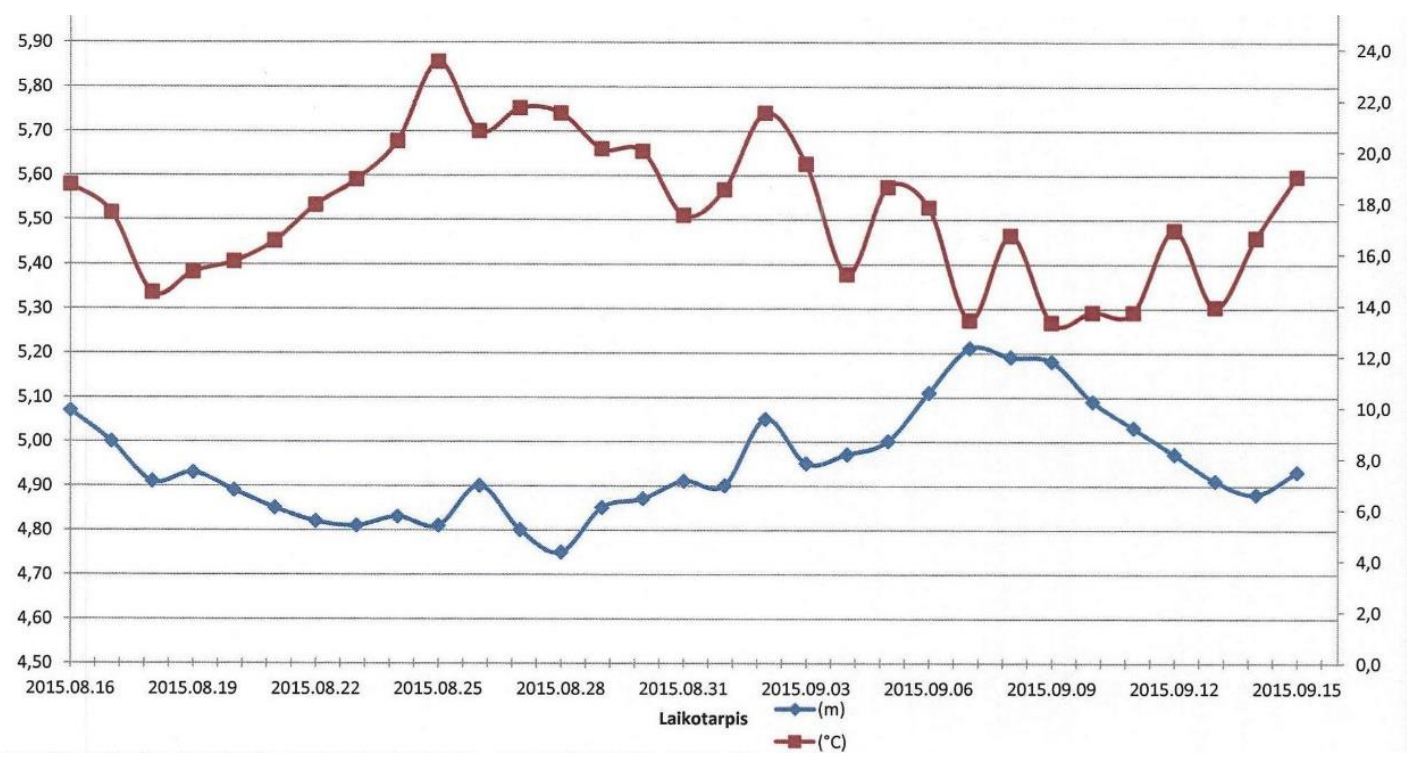

Fig. 8. Diagram of the sea level and temperature changes

Some problems were faced with during experimental measurements:

- Prisms (10 points at Southern and Northern Breakwaters) were broken because of a strong wind, high waves and damaged by people. Some prisms were turned; therefore, instruments could not find a position and perform measurements. Due to this reason it is necessary to change or regulate prisms continuously.

- Damage of the cracks-gauge (2 locations were not fixed).

- Disconnection of power supply (when carrying out the construction work) - a tacheometer was not active for several days.
- A broken antenna of data coupled the device.

\section{Conclusion}

The used breakwaters monitoring system which consists of two different types of measurement instruments involves the whole required procedures for breaks prevention and realization of all technical requirements for breakwaters' observation: the detailed recognition of experimental area, the thorough selection of measuring instruments and their installation points, setting up of prisms and an overview of locations for cracks determination; automatic processing of data sets which are continuously generated by sensors. 
A huge data set was constructed for the analysis 10,100 observations; this provided the base for further investigation of deformation assessment, the determination of seasonal influence on breakwaters' parameters and also allowed to compare the difference of an impact depending on the location of the breakwater. The review of monitoring results shows that the significant changes of breakwaters slopes' fastening elements (points' displacements, cracks of chosen locations) were not detected. All measured elements remained stable, any deformations or slumps were unobserved, but still a further analysis is required.

Breakwaters' stability extremely depended on meteorological conditions because the wind induced waves and currents, storms, air temperature; moreover, negative actions of humans interrupted measurements' procedure. Therefore, stability of the measured elements could be temporary and it is recommended that breakwaters' monitoring should be carried out continuously.

\section{References}

1. British Standard-British Standard 6349-7_ 1991, Code of practice for maritime structures, Part 7_ Guide to the design and construction of. BS 6349-7:1991

2. Bucksch H. (1997) Dictionary Geotechnical Engineering, Springer, 30/3136 - 543210, 1997

3. Antunes P., Travanca R., Rodrigues H., Melo J., Jara J., Varum H., André P (2012) Dynamic Structural Health Monitoring of Slender Structures Using Optical Sensors. Sensors 2012, 12, 6629-6644

4. Moreau F., Dauteuil O., Bour O., Gavrilenko (2006) GPS measurements of ground deformation induced by water level variations into a granitic aquifer (French Brittany), Terra Nova, 18, 50-54, 2006

5. Matsuya I., Katamura R., Sato M., Iba M., Kondo H., Kanekawa K., Takahashi M., Hatada T., Nitta Y., Tanii T., Shoji S., Nishitani A., Ohdomari I. (2010) Measuring Relative - Story Displacement and Local Inclination Angle Using Multiple Position Sensitive Detectors, Sensors, 2010, 10, 9687-9697;

6. Choudhury M., Rizos C. (2010) Slow structural deformation monitoring using Locata - a trial at Tumut Pond Dam, Journal of Applied Geodesy 4 (2010), 177-1876de Gruyter 2010.

7. Guo J., Zhou M., Wang C., Mei L. (2012) The application of the model of coordinate S-transformation for stability analysis of datum points in high-precision GPS deformation monitoring networks; Journal of Applied Geodesy, Vol.6(2012). 